\title{
AUTOMATED SCREENING METHOD FOR THE WASSERMANN REACTION*
}

\author{
BY \\ V. W. PUGH AND R. W. T. GAZE \\ Department of Clinical Pathology, the Leicester Royal Infirmary
}

For a number of years we have considered the Wassermann reaction to be eminently suitable for complete automation. It was after our experience with the Technicon Autoanalyser doing chemical analyses that we decided to experiment with the Wassermann reaction. The following paper records the details of our method, based on the Whitechapel technique (Wilkinson, 1962). It does not include details of the experimental work started in October, 1963.

\section{Complement-Haemolysin Titration}

\section{(A) Materials}

(1) Complement-Freeze-dried from Burroughs Wellcome.

(2) Haemolysin-Stayne Laboratories

(3) Sheep cells-Burroughs Wellcome

(4) Buffered saline-

Sodium chloride (AR) $85 \cdot 0 \mathrm{~g}$.

Barbitone (BP) $6 \cdot 3 \mathrm{~g}$.

Sodium barbitone (BP) $3 \cdot 3 \mathrm{~g}$.

Magnesium chloride $6 \mathrm{H}_{2} \mathrm{O}(\mathrm{AR}) 1.01 \mathrm{~g}$.

70-75 per cent. Calcium chloride (AR) $0 \cdot 1 \mathrm{~g}$.

Distilled water $10 \cdot 0$ litres.

(5) Manifold - as for Wassermann reaction proper without time delay coils between A and B in Fig. 1 (overleaf).

Note: (a) A G3 cactus joins pump tubes 5, 7, and 9 .

(b) The capillary $\mathrm{H}$ used at the injection of the sheep cells has a piece of polyethylene (PE) tubing $0.015 \times 0.043$ inserted into the capillary arm.

(c) A pump tube 0.015 is used as the transmission line for the sheep cells.

\section{(B) Method}

(1) Wash sheep cells thrice with buffered saline. Prepare a 5 per cent. suspension.

\footnotetext{
* Received for publication August 31, 1964
}

(2) Prepare dilutions of haemolysin in buffered saline over a range $1 / 500-1 / 6,000$.

(3) Reconstitute dried complement by adding $2 \mathrm{ml}$. glass-distilled water to the ampoule and stand until dissolved. 1 volume of reconstituted complement and 7 volumes of glass-distilled water, as directed by the manufacturer, equals $1 / 10$ dilution of guinea-pig serum. Dilutions of complement are then prepared over a range $1 / 60-1 / 100$. Each dilution should be not less than $8 \mathrm{ml}$. in volume to provide sufficient for the "run". The dilutions are kept in the refrigerator until required.

(4) Sensitize 1 volume quantities of sheep cells with 1 volume of each haemolysin dilution and put into autoanalyser cups and place seriatim in the sampler with buffered saline wash between. The sensitized sheep cells are pumped via tube 13 ; complement is pumped via tube 5 ; all other tubes pump buffered saline (Fig. 1, overleaf).

(5) Speed of sampling is 60 /hour with a buffered saline wash between. The standard colorimeter with a $15 \mathrm{~mm}$. flow cell and 660 filter is used.

\section{(C) Results}

In the haemolysin-complement titration, the combination of the weakest dilution of complement with the weakest dilution of haemolysin which gives complete haemolysis is used for calculating the strength of the haemolytic system in the Wassermann reaction. In (Fig. 2, overleaf) complete haemolysis is given by a dilution of complement at $1 / 100$ and a dilution of haemolysin at 1/1,000.

\section{Wassermann Reaction Proper}

(A) Materials.-These are as for the complementhaemolysin titration together with antigen from the VD Reference Laboratory used at the titre stated. The test sera are inactivated in the usual way. 


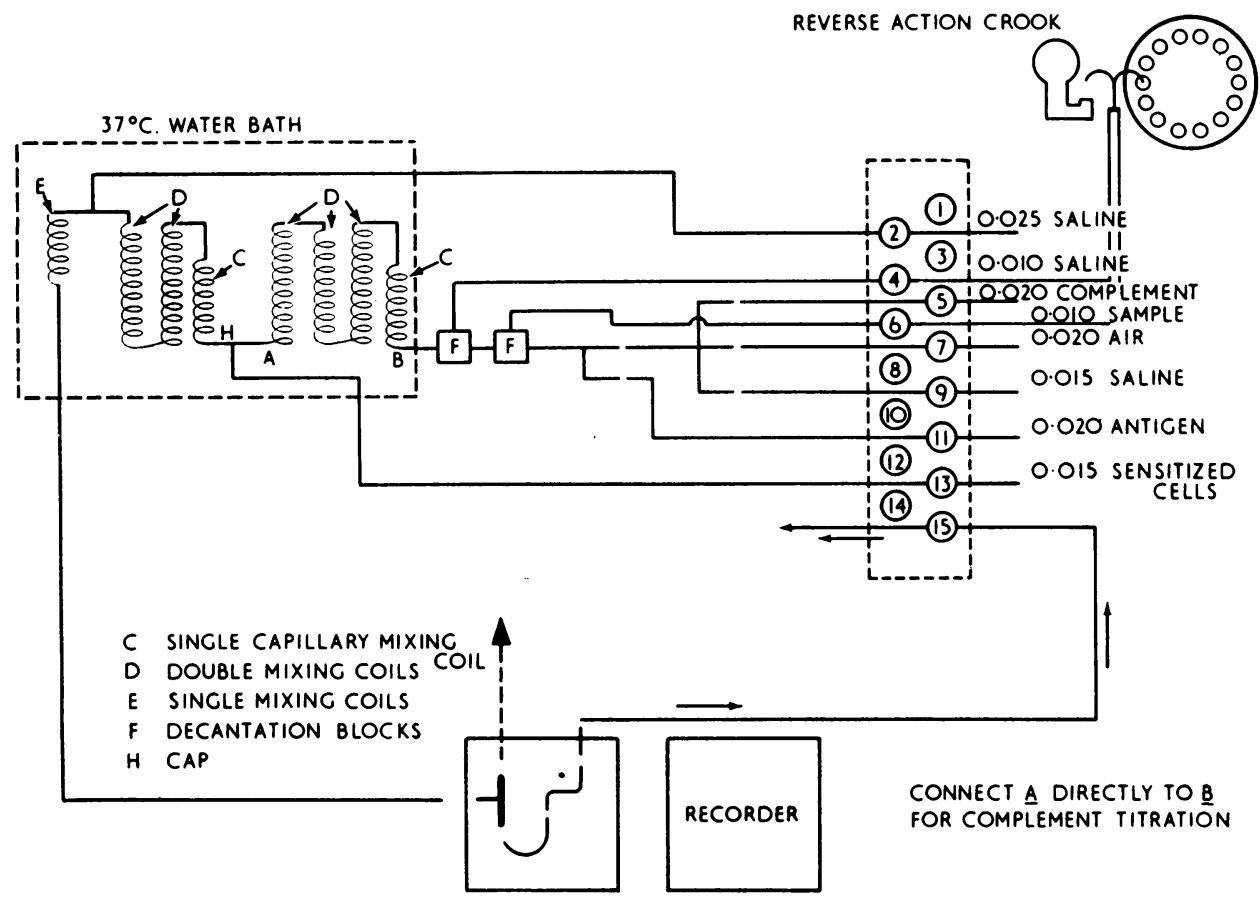

FIG. 1.-Flow diagram.

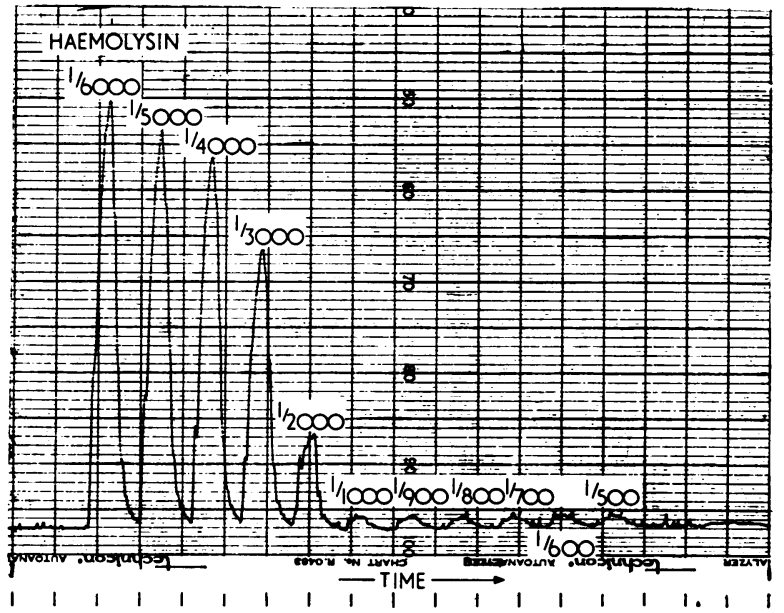

FIG. 2.-Complement haemolysin titration (Complement 1/100).

(B) Method.-Clear unhaemolysed sera only should be used, these are placed in cups in the sampler alternately with cups of buffered saline, and pumped via tube 6 (Fig. 1). "Backwash" using buffered saline is arranged using a reverse action crook and pumped via tube 4 . The appropriate dilution of complement is pumped via tube 5 . The strength of the complement used is twice the strength of that giving complete haemolysis in the complement-haemolysin titration (CHT), e.g. if the strength of the complement in CHT is $1 / 100$, use $1 / 50$ for the WR. The haemolysin strength is $1 \frac{1}{3}$ times that obtained for the comparable complement titre in the CHT, e.g. haemolysin $1 / 1,000$ in $\mathrm{CHT}$, use at $1 / 750$ in WR. The complement must be kept cool throughout the test in a bath of iced water. All other tubes are arranged as per flow diagram (Fig. 1). The time delay coils are kept at $37^{\circ} \mathrm{C}$. in a water bath. The standard colorimeter with $15 \mathrm{~mm}$. flow cell and 660 filter is again used and the sampling rate is 60 /hour.

All reagents, except the sensitized sheep cells, are pumped for approximately one hour to wash the system through. Then the sensitized sheep cells are pumped until a stable base line is obtained-approximately 10 minutes. Then the sera are sampled in the usual way.

(C) Interpretation.-A pool of negative sera is included in each batch of tests and usually gives a peak of up to seven transmission lines, depending on the pool (Peak 4, Fig. 3). Any sample giving a peak of more than one transmission line greater than the pooled negative is regarded as positive.Fig. 3 (opposite) 
shows part of the record of a routine run; Peaks 1 and 38 are weak positive results and Peaks 10 and 16 are strong positive results. The other peaks are negative results. It will be seen that very strong positive reactions give peaks of over 25 transmission lines higher than the negatives. It should be noted that the peak of a serum following a strong positive will be incorporated in the base of the positive peak and should be repeated at the end of the run (Peaks 12 and 18, Fig. 3).

(D) Results.-The sera used were specimens sent for routine WR. The manual method was carried out by Dr E. M. Stirk and the samples were then passed to us for the automated process. Where the results were at variance, the sera were tested by Dr P. J. L. Sequiera at the Central Serological Laboratory, Manchester.

Nine hundred routine tests were performed of which 25 gave positive reactions by both manual and automated methods; 787 gave negative reactions by both methods; whilst 88 did not agree with the manual method (EMS), 51 were machine positive whilst the manual result was negative and 37 results were machine negative whilst the manual method (EMS) was positive.
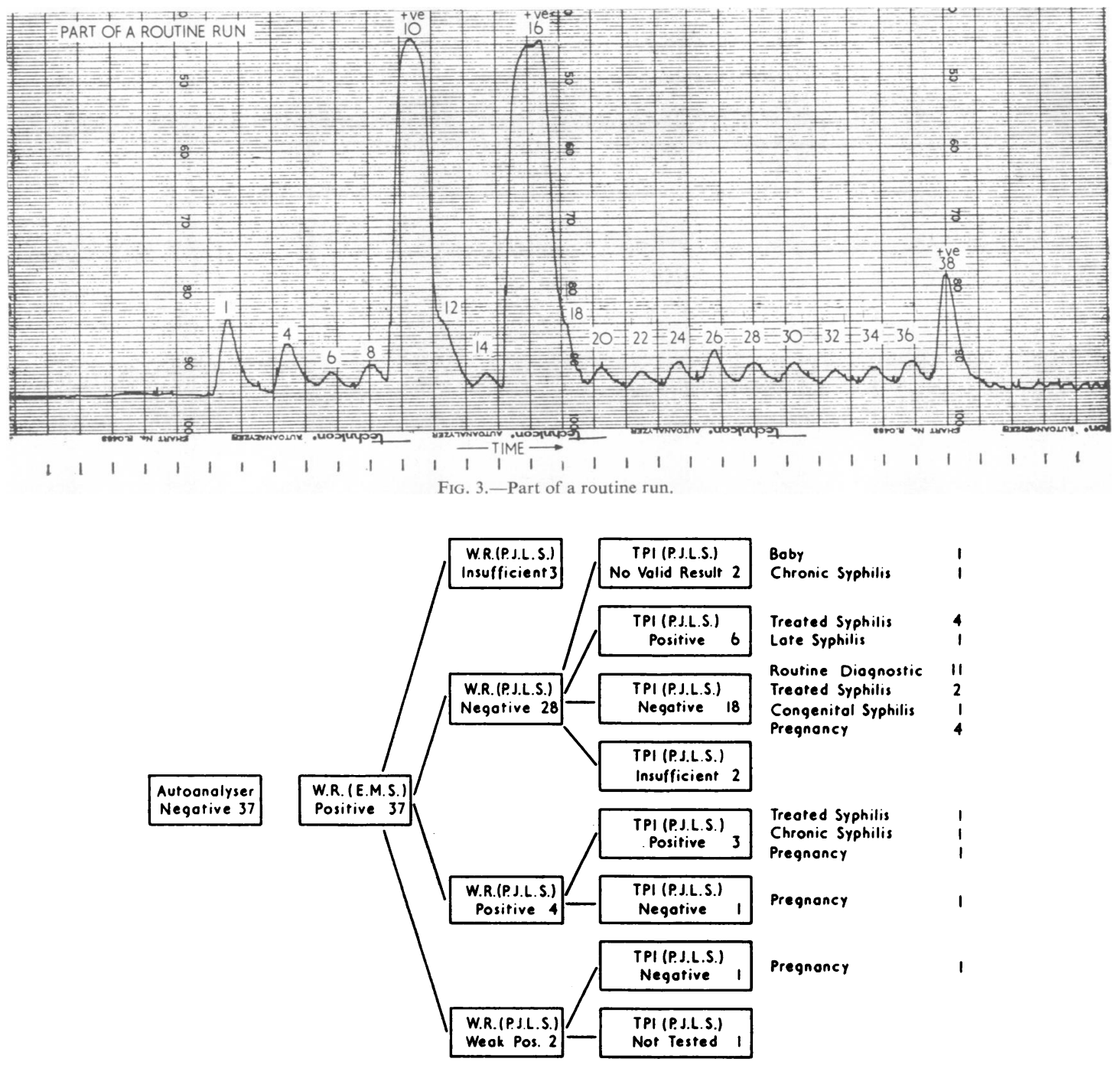

FIG. 4.-Analysis of discrepant results between autoanalyser and manual methods, using standard antigen (see next page). 
Forty-four of the machine positive group were tested by PJLS (there was insufficient serum from seven), when 43 were confirmed as negative and one was anticomplementary. This discrepancy is explained in forty instances because the sera were turbid, fatty, or grossly haemolysed. No explanation could be found in the others, but it is worthy of note that three of these sera gave positive results with the VDRL test.

Thirty-four of the machine negative group, which were positive by the manual method (EMS), were tested by PJLS (there was insufficient serum from three), when 28 sera were confirmed as negative, four were positive and two weakly positive. Six of these confirmed negatives were TPI positive and five were from cases of treated syphilis. Three of the positives (PJLS) were TPI positive, two were from cases of treated syphilis, the other one was TPI negative. One of the weakly positive WR (PJLS) was TPI negative and was from a pregnant woman; the other was not examined by the TPI test and was from a case of syphilis under treatment (Table I and Fig. 4; Table II, opposite).

\section{Conclusions}

The automated method matched against one manual method (EMS) yielded an error of 9.7 per cent. of which $5 \cdot 6$ per cent. were false positives. This error would be greatly reduced to 1.55 per cent. if obviously cloudy or grossly haemolysed sera had

TABLE I

AUTOMATED METHOD POSITIVE: MANUAL (EMS) METHOD NEGATIVE

\begin{tabular}{|c|c|c|c|c|c|c|c|c|c|c|}
\hline \multirow{2}{*}{ No. } & Machine & \multicolumn{3}{|c|}{ Manual (EMS) } & \multicolumn{5}{|c|}{ Central Serological Laboratory } & \multirow{2}{*}{ Remarks } \\
\hline & WR & WR & PPR & VDRL & WR & PPR & TPI & RPCF & CWR & \\
\hline $\begin{array}{r}3 \\
17 \\
24 \\
28 \\
29 \\
33 \\
34 \\
36 \\
41 \\
47 \\
48 \\
49 \\
50 \\
51 \\
52 \\
53 \\
56 \\
61 \\
62 \\
64 \\
66 \\
70 \\
75 \\
82 \\
86 \\
87 \\
90 \\
91 \\
92 \\
95 \\
96 \\
97 \\
98 \\
99 \\
100 \\
101 \\
102 \\
103 \\
104 \\
105 \\
107 \\
108 \\
109 \\
112 \\
113 \\
115 \\
116 \\
117 \\
119 \\
121 \\
126 \\
\end{array}$ & $\begin{array}{l}+ \\
+ \\
+ \\
+ \\
+ \\
+\end{array}$ & $\begin{array}{l}= \\
= \\
= \\
= \\
= \\
= \\
= \\
= \\
= \\
=\end{array}$ & $\begin{array}{l}- \\
= \\
= \\
= \\
- \\
= \\
= \\
= \\
= \\
= \\
= \\
= \\
= \\
= \\
= \\
= \\
= \\
= \\
= \\
= \\
= \\
= \\
= \\
= \\
= \\
= \\
= \\
= \\
\overline{-} \\
\mathbf{N T} \\
\mathbf{N T} \\
\mathbf{N T} \\
\mathbf{N T} \\
\mathbf{N T} \\
\mathbf{N T} \\
\mathbf{N T} \\
\mathbf{N T} \\
\mathbf{N T} \\
\mathbf{N T} \\
\mathbf{N T} \\
\mathbf{N T} \\
\mathbf{N T} \\
\mathbf{N T} \\
\mathbf{N T}\end{array}$ & 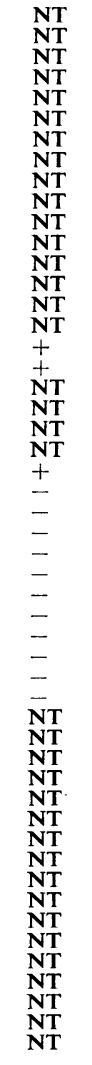 & 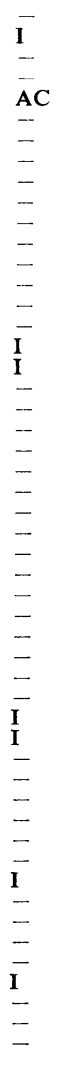 & 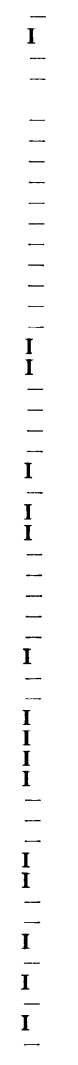 & $\begin{array}{l}\bar{I} \\
- \\
- \\
- \\
- \\
- \\
- \\
- \\
- \\
- \\
- \\
- \\
- \\
\bar{I} \\
\mathbf{I} \\
- \\
- \\
- \\
\bar{I} \\
\bar{I} \\
\mathbf{I} \\
\mathbf{N T} \\
\mathbf{N T} \\
\mathbf{N T} \\
- \\
- \\
\overline{-} \\
\mathbf{N T} \\
\mathbf{I} \\
\mathbf{I} \\
\overline{\mathbf{N T}} \\
- \\
- \\
\mathbf{I} \\
\mathbf{I} \\
- \\
- \\
\mathbf{N T} \\
\mathbf{I} T \\
\mathbf{N} \\
- \\
\end{array}$ & 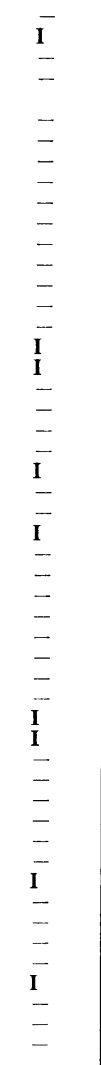 & 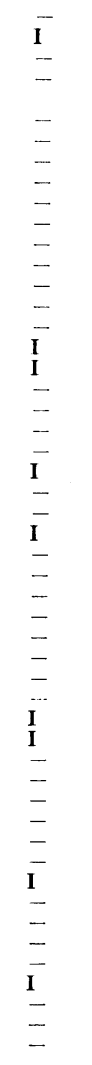 & $\begin{array}{l}2 \text { TL above } \\
\text { Discoloured serum } \\
\text { Turbid serum } \\
\text { Haemolysed } \\
1 \text { TL above } \\
3 \text { TL above } \\
1 \text { TL above } \\
\text { Turbid serum } \\
\text { Turbid serum } \\
\text { Turbid serum } \\
\text { Turbid serum } \\
\text { Turbid serum } \\
\text { Turbid serum } \\
\text { Turbid serum } \\
2 \text { TL above } \\
1 \text { TL above } \\
\text { Turbid serum } \\
\text { Fatty serum } \\
\text { Haemolysed } \\
\text { Fatty serum } \\
\text { Discoloured serum } \\
\text { Turbid serum } \\
\text { Turbid serum } \\
\text { Turbid serum } \\
\text { Turbid serum } \\
\text { Turbid serum } \\
\text { Turbid serum } \\
\text { Turbid serum } \\
\text { Turbid serum } \\
\text { Turbid serum } \\
\text { Turbid serum } \\
\text { Turbid serum } \\
\text { Turbid serum } \\
\text { Turbid serum } \\
\text { Turbid serum } \\
\text { Turbid serum } \\
\text { Turbid serum } \\
\text { Turbid serum } \\
\text { Turbid serum } \\
\text { Turbid serum } \\
\text { Turbid serum } \\
\text { Turbid serum } \\
\text { Turbid serum } \\
\text { Turbid serum } \\
\text { Tuld }\end{array}$ \\
\hline
\end{tabular}


TABLE II

AUTOMATED METHOD NEGATIVE: MANUAL (EMS) METHOD POSITIVE

\begin{tabular}{|c|c|c|c|c|c|c|c|c|c|c|}
\hline \multirow[b]{2}{*}{ No. } & Machine & \multicolumn{3}{|c|}{ Manual (EMS) } & \multicolumn{5}{|c|}{ Central Serological Laboratory } & \multirow{2}{*}{ Remarks } \\
\hline & WR & WR & PPR & VDRL & WR & PPR & TPI & RPCF & CWR & \\
\hline $\begin{array}{r}1 \\
2 \\
6 \\
10 \\
12 \\
14 \\
19 \\
20 \\
23 \\
25 \\
31 \\
35 \\
37 \\
39 \\
40 \\
42 \\
43 \\
44 \\
45 \\
46 \\
63 \\
67 \\
68 \\
72 \\
73 \\
77 \\
79 \\
83 \\
84 \\
85 \\
89 \\
110 \\
111 \\
120 \\
123 \\
124 \\
125\end{array}$ & $\begin{array}{l}- \\
- \\
- \\
- \\
- \\
- \\
- \\
- \\
- \\
- \\
- \\
- \\
- \\
- \\
- \\
- \\
- \\
- \\
- \\
- \\
- \\
- \\
- \\
- \\
- \\
- \\
-\end{array}$ & $\begin{array}{l}\mathbf{w} \\
+1- \\
+ \\
\mathbf{w} \\
+ \\
+ \\
+1- \\
+ \\
+1- \\
+1- \\
+ \\
+ \\
+ \\
+ \\
++ \\
+ \\
\mathbf{w} \\
+ \\
\mathbf{w} \\
+1- \\
+1- \\
+ \\
+ \\
+ \\
+1- \\
\mathbf{w} \\
+ \\
\mathbf{w} \\
\mathbf{w} \\
\mathbf{w} \\
\mathbf{w} \\
\mathbf{w} \\
\mathbf{w} \\
\mathbf{w} \\
+ \\
+ \\
+\end{array}$ & $\begin{array}{l}\text { NT } \\
- \\
- \\
+1 \\
+ \\
- \\
+ \\
- \\
+ \\
\text { NT } \\
+ \\
+ \\
- \\
- \\
- \\
- \\
- \\
- \\
+1- \\
- \\
+ \\
- \\
- \\
- \\
- \\
- \\
- \\
- \\
- \\
- \\
-\end{array}$ & $\begin{array}{l}\text { W } \\
+ \\
+ \\
++ \\
++ \\
++ \\
\text { NT } \\
++ \\
++ \\
++ \\
+ \text { NT } \\
+ \\
+ \\
- \\
\text { NT } \\
\text { NT } \\
\text { NT } \\
\text { NT } \\
\text { + } \\
++ \\
+ \\
\text { NT } \\
++ \\
+ \\
+ \\
+ \\
\text { NT } \\
\text { NT } \\
\text { NT } \\
+++ \\
\text { NT } \\
\text { NT } \\
\text { NT } \\
\text { NT } \\
+++\end{array}$ & $\begin{array}{l}- \\
+ \\
\mathbf{I} \\
\overline{+} \\
\mathbf{I} \\
\overline{+} \\
\overline{\mathbf{W}} \\
- \\
- \\
- \\
- \\
- \\
\overline{+} \\
- \\
- \\
- \\
- \\
- \\
- \\
- \\
- \\
- \\
\overline{\mathbf{W}} \\
- \\
- \\
\mathbf{I} \\
- \\
-\end{array}$ & $\begin{array}{l}I \\
I \\
I \\
I \\
I \\
I \\
I \\
- \\
- \\
- \\
- \\
- \\
- \\
- \\
- \\
I \\
- \\
- \\
- \\
- \\
I \\
I \\
- \\
- \\
- \\
I \\
I \\
- \\
-\end{array}$ & $\begin{array}{l}+ \\
+ \\
+ \\
\mathbf{I} \\
+ \\
+ \\
\bar{I} \\
+ \\
+ \\
- \\
\overline{+} \\
+ \\
- \\
- \\
- \\
\mathbf{I} \\
- \\
\overline{+} \\
+ \\
- \\
- \\
\overline{\mathbf{N}} \\
\mathbf{N V} \\
- \\
- \\
\overline{-} \\
\mathbf{N} T \\
\mathbf{I} \\
\mathbf{I} \\
- \\
+ \\
+\end{array}$ & $\begin{array}{l}- \\
- \\
\mathbf{I} \\
+ \\
+ \\
- \\
\mathbf{I} \\
\mathbf{W} \\
- \\
- \\
- \\
+ \\
- \\
- \\
- \\
- \\
- \\
- \\
- \\
- \\
- \\
- \\
- \\
- \\
+ \\
- \\
- \\
+ \\
- \\
- \\
- \\
- \\
-\end{array}$ & $\begin{array}{l}- \\
+ \\
+ \\
\mathbf{I} \\
+ \\
+ \\
\mathbf{I} \\
+ \\
+ \\
- \\
+ \\
+ \\
- \\
- \\
- \\
- \\
+ \\
\mathbf{W} \\
- \\
- \\
- \\
- \\
- \\
- \\
- \\
- \\
+ \\
\mathbf{W} \\
\mathbf{I} \\
-\end{array}$ & $\begin{array}{l}\text { Treated syphilis } \\
\text { Congenital syphilis } \\
\text { Baby } \\
\text { Chronic syphilis } \\
\text { Pregnancy } \\
\text { Pregnancy } \\
\text { Pregnancy } \\
\text { Syphilis on Treatment } \\
\text { Treated old case } \\
\\
\text { Treated syphilis }\end{array}$ \\
\hline
\end{tabular}

been excluded. Of the $4 \cdot 1$ per cent. "false negative" results when compared with EMS, only 0.66 per cent. were confirmed "false negative" by PJLS. $21 \cdot 8$ per cent. of the machine "false negatives" which were confirmed as negative by PJLS yielded positive TPI tests. It is of interest to note that the nine cases in which the TPI test was positive and the W.R. by machine was negative and by either of the manual methods was positive or negative, were all from known cases of syphilis under treatment.

Provided that grossly haemolysed or turbid sera are excluded, we consider that this automated method for the Wassermann reaction is as reliable as the present manual methods for the standard WR and, provided that the present practice of using other serological tests in addition to the WR is continued, errors will be minimal.

Our thanks are due to Dr E. M. Stirk and Dr P. J. L. Sequiera for carrying out the many serological tests and making their results available to us, to Mr Haddock for the diagrams and figures, and to Mr Michael Ducros of Technicon Instruments Co. Ltd for helpful discussions at the beginning of this work.

\section{ADDENDUM}

The results reported above, using crude heart extract antigen from the VD Reference Laboratory, yielded a number of discrepancies when compared with the Manual methods. In an attempt to reduce these differences it was decided to try the Maltaner antigen as recommended by Wilkinson (1962) as being more sensitive and probably slightly more specific. This addendum reports the results of 1,000 tests using this antigen.

Materials and Method.-These were exactly as described above except that Maltaner antigen, made by Burroughs Wellcome \& Co., was used. As before, the sera used were from the routine manual Standard WR (Dr E. M. Stirk) and, where the results were at variance, the sera were tested at the Central Serological Laboratory, Manchester (Dr P. J. L. Sequeira). In addition, all sera giving positive peaks on the Autoanalyser were repeated at the end of each run in the absence of antigen to ascertain anticomplementary activity of the sample.

Results.-Of the 1,000 routine samples tested, 48 
gave positive, 924 gave negative, and two gave anticomplementary reactions by both methods. There were 26 discrepancies (Table III).

Two were positive by machine and negative by manual (EMS) technique; one of these was confirmed negative by PJLS, and there was insufficient serum for the other sample to be tested, though the serum gave a positive VDRL (EMS).

TABLE III

DISCREPANCIES BETWEEN AUTOMATED AND MANUAL (EMS) METHOD

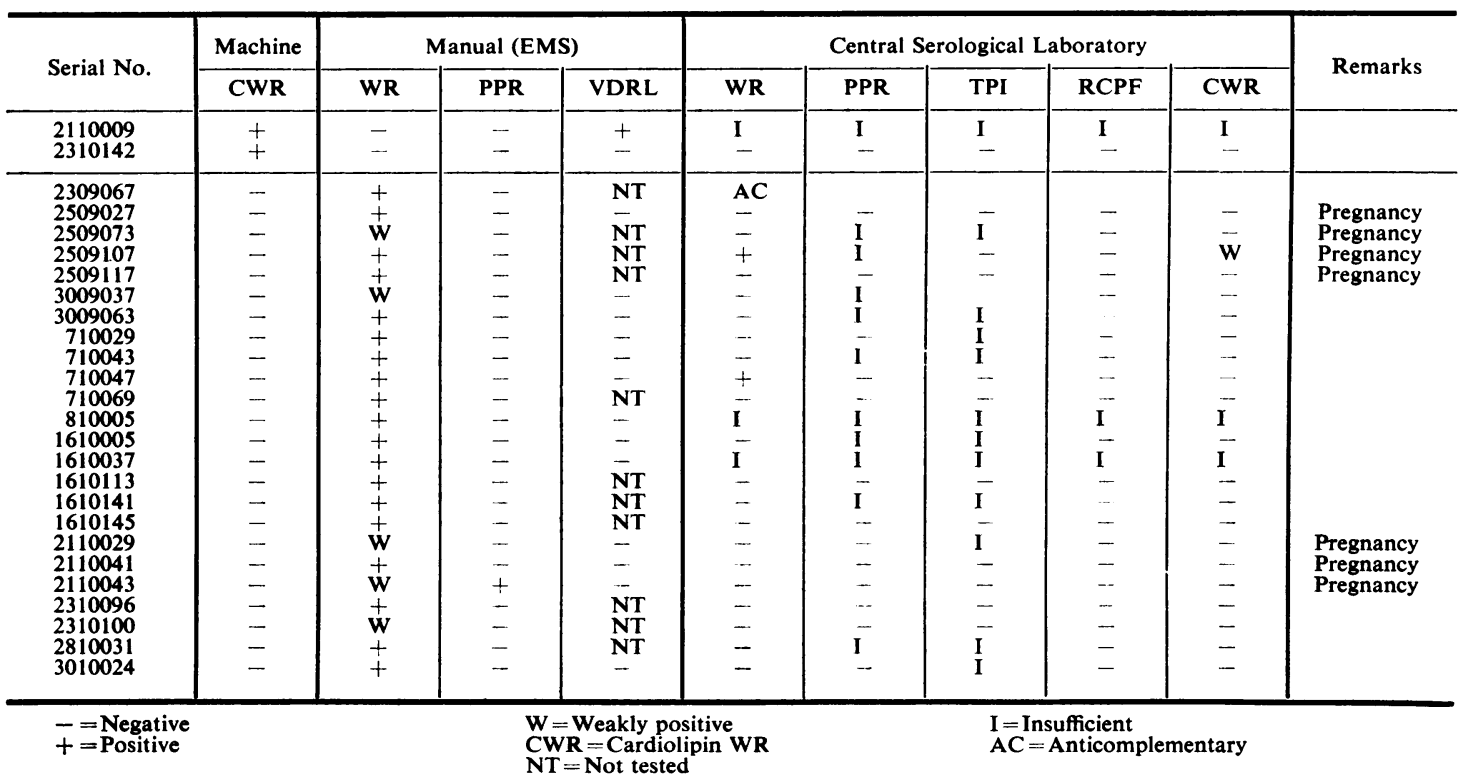

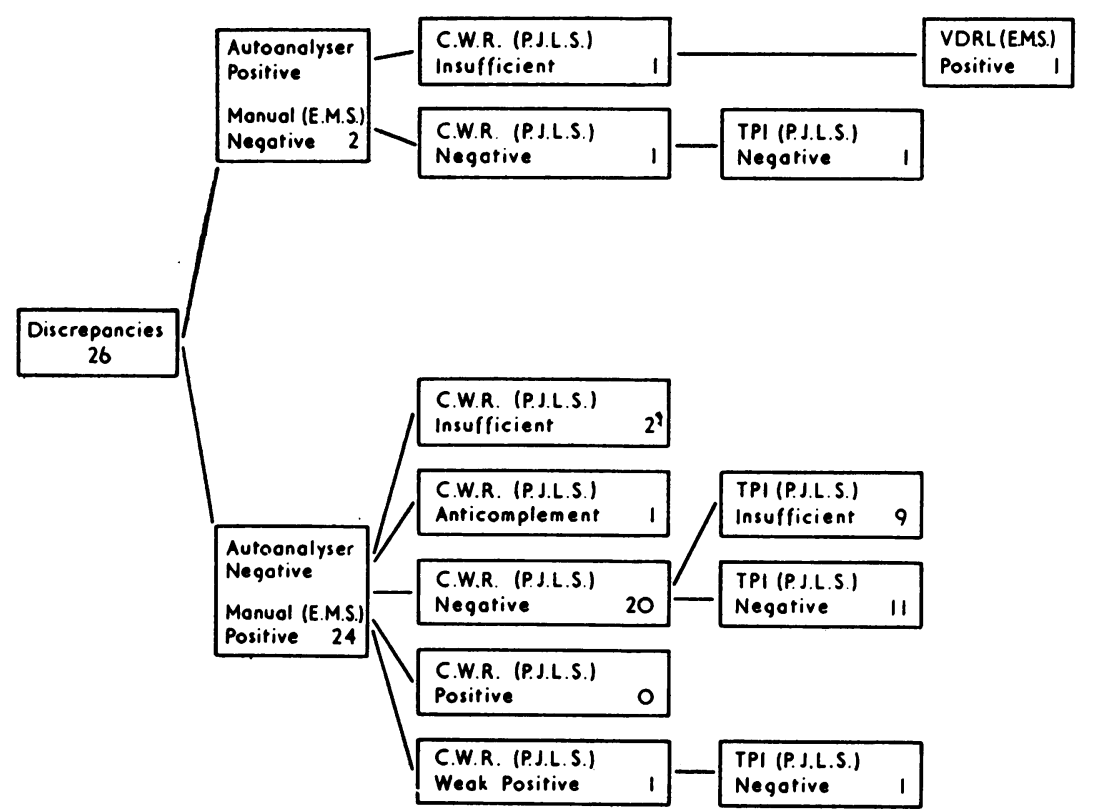

FIG. 5.-Analysis of discrepant results between autoanalyser and manual methods, using Maltaner antigen. 
Twenty-four were negative by machine and positive or weak positive by manual (EMS) method, 22 of these were tested by PJLS (there was insufficient serum from two), and twenty were confirmed negative cardiolipin WR, one was anticomplementary, and one was weakly positive although the TPI was negative (Fig. 5, see previous page.)

\section{Conclusions}

The use of the Maltaner antigen in the automated WR is satisfactory, and the results obtained show excellent agreement when compared with the manual cardiolipin WR - there being one false positive and one false negative in 997 samples completely tested, although in the latter instance the TPI was negative.

\section{Summary}

The successful modification of the Whitechapel technique for the Wassermann reaction for use on the Technicon Autoanalyser is described.

1,000 sera were tested using crude heart-extract antigen; 51 false positive and 37 false negative results were obtained when compared with the results obtained by manual methods. A further 1,000 sera were tested using Maltaner antigen (see Addendum), and one false positive and one false negative were obtained.
An analysis of these discrepancies is made by considering the results of other serological tests in addition to the Wassermann reaction.

This automatic technique provides a reliable screening method for the Wassermann reaction of sera.

\section{REFERENCE}

Wilkinson, A. E. (1962). "Serological Tests for Syphilis." Association of Clinical Pathologists. Broadsheet No. 41 (New Series). October, 1962.

Méthode de détection automatique de la réaction de Wassermann

\section{RÉSUMÉ}

On décrit l'heureuse modification de la technique de Whitechapel pour la réaction de Wassermann qu'apporte l'utilisation de l'analyseur automatique "Technicon".

On testa 1,000 sérums en utilisant un antigène à base d'extraits crus de coeur; on obtint 51 résultats faussement positifs et 37 faussement négatifs par rapport aux résultats obtenus par les méthodes manuelles. On testa une autre série de 1,000 sérums en utilisant l'antigène Maltaner; on obtint un résultat faussement positif et un résultat faussement négatif. On fait une analyse de ces résultats discordants en considérant les résultats obtenus avec des tests sérologiques autres que la réaction de Wassermann.

Cette technique automatique fournit une méthode de détection sûre de la réaction sérologique de Wassermann. 